\title{
A INCOMPATIBILIDADE ENTRE O MODELO PROCESSUAL DOS JUIZADOS ESPECIAIS CRIMINAIS E A COMPLEXIDADE DA PORNOGRAFIA DE VINGANÇA
}

\author{
Artenira da Silva e Silva ${ }^{1}$ \\ Rossana Barros Pinheiro ${ }^{2}$
}

\section{Resumo}

Trata-se de um estudo acerca da incompatibilidade entre a estrutura processual dos juizados especiais criminais estabelecida na Lei 9099/95 e o tratamento da pornografia de vingança, violência de gênero que exige, necessariamente, a aplicação da Lei Maria da Penha e a consequente fixação da competência para conhecimento e julgamento em varas especializadas da mulher e da violência doméstica. Destaca-se a imperícia dos operadores do Direito enquanto fator determinante dessa fixação de competência, que naturaliza as consequências altamente danosas da pornografia de vingança sobre a vida das vítimas, equiparando esse delito a meros crimes de menor potencial ofensivo, logo, desconectados de sua natureza de violência de gênero intrafamiliar. Discutem-se os principais retrocessos dessa fixação de competência no enfrentamento efetivo da violência de gênero, apontandose a adoção de abordagens transdisciplinares como a melhor forma de compreender e manejar a complexidade da pornografia de vingança, repensando-se a competência jurisdicional para o enfrentamento de tal crime. Para concretização dos fins propostos, foram adotados os seguintes procedimentos de pesquisa: pesquisa de campo, pesquisa documental, pesquisa bibliográfica e pesquisa normativa, utilizando-se o procedimento de análise de conteúdo para tratamento dos dados obtidos.

Palavras-chave: Pornografia de Vingança, Violência de Gênero, Lei Maria da Penha, Lei 9099/95, Juizados

\footnotetext{
${ }^{1}$ Pós-doutora em Psicologia e Educação pela Universidade do Porto. Docente e Pesquisadora do Departamento de Saúde Pública e do Programa de Pós-Graduação em Direito e Instituições do Sistema de Justiça/UFMA. Coordenadora da Linha de Pesquisa do Observatório Ibero Americanode Saúde e Cidadania e Coordenadora do Observatorium de Segurança Pública (PPGDIRUFMA/CECGP).E-mail: artenirassilva@hotmail.com

${ }^{2}$ Mestranda do Programa de Pós-Graduação em Direito e Instituições do Sistema de Justiça. Membro da Equipe da Revisão da Revista do Curso de Direito. Bolsista da CAPES. E-mail: rossana.barros@hotmail.com
} 
Especiais Criminais.

\section{INTRODUÇÃO}

A divulgação não autorizada da intimidade e sexualidade femininas enquanto forma de represália ao fim de relacionamentos afetivos e/ou sexuais tem figurado como prática recorrente no cotidiano brasileiro, implicando assim em desafios institucionais quanto ao enfrentamento jurídico efetivo do problema.

Infelizmente a utilização de abrordagens transdisciplinares para o manejo de fenômenos complexos ainda é rara no Brasil, onde se observa principalmente a vigência de um entendimento jurisprudencial majoritário deveras simplista e deficiente quanto à tipificação da pornografia de vingança, frequentemente criminalizada apenas enquanto crime contra a honra, deixando-se assim de dar atenção aos graves desequilíbrios psicológicos implicados à saúde das vítimas em virtude da prática de violência de gênero.

Por conta desse raciocínio limitado, que visualiza tão somente os prejuízos causados à honra objetiva e subjetiva das vítimas, predominantemente mulheres, a competência processual para o conhecimento e julgamento dos crimes de pornografia da vingança tem sido fixada nos Juizados Especiais Criminais, haja vista a aderêcia desses aos delitos de menor potencial ofensivo, como injúria e difamação desconectadas da violência de gênero, conforme a tipificação do Código Penal.

Nesse sentido, observa-se que o referencial legislativo, processual e institucional dos juizados tem se mostrado claramente incompatível com o enfrentamento devido da pornografia de vingança, haja vista o objetivo político da criação dessas instâncias no sentido de ampliar o acesso a justiça, evitando para tanto o prosseguimento da persecução criminal através da adoção preferencial de institutos criminais despenalizadores.

Diante de todo o exposto, torna-se urgente a realização de estudos científicos aptos a para fomentar a aplicação da Lei Maria da Penha ao crime de pornografia de vingança, com a consequente fixação da competência processual para o enfrentamento destes crimes nas varas especializadas em violência contra a mulher, considerando a total falta de correspondência entre a complexidade do delito e o simplismo institucional presente na Lei 9099/95, que disciplina o funcionamento dos juizados especiais.

Tal abordagem se revela últil à medida que esclaresce os principais problemas criados pela aplicação dessa legislação ao crime em estudo. A utilização do modelo processual previsto na Lei 9099/95 para o enfrentamento da pornografia da vingança favorece decisões que invisibilizam a gravidade destes crimes e implicam sensivelmente no tratamento institucional pouco efetivo da matéria nos diferentes estados do Brasil.

Para concretização dos fins propostos, foi adotada uma metodologia que comtemplou os seguintes 
procedimentos de pesquisa: pesquisa de campo, pesquisa documental, pesquisa bibliográfica e pesquisa normativa, utilizando-se o procedimento de análise de conteúdo para tratamento dos dados obtidos.

A pesquisa de campo foi realizada junto ao Primeiro Juizado Especial Criminal (JECRIM) da cidade de São Luís-MA, unidade institucional do TJMA, atualmente responsável pelo recebimento de Termos Circunstanciados referentes a injúrias, difamações e ameaças praticadas com o auxílio de dispositivos tecnológicos em redes sociais.

Considerando a ausência de um instrumento informatizado que permita a identificação dos fatos que ensejaram as ações penais em tramitação no Primeiro JCRIM, sendo possível acessar tão somente decisões e sentenças pelo sistema processual jurisconsult do TJMA, realizou-se uma busca manual minuciosa em todo acervo da unidade após a autorização da realização da pesquisa na unidade.

Feito o levantamento, foi necessária a filtragem dos processos encontrados, de forma a comtemplar-se especialmente aqueles que apresentam a prática de crimes contra a honra dentro de um contexto de relacionamento afetivo entre homem e mulher ou entre duas mulheres, configurando violência psicológica e/ou moral de gênero, de forma a promover a localização da amostra dentro dos limites embasados pelo referencial teórico.

Para melhor contemplar os objetivos do presente estudo optou-se por realizar um estudo de caso, analisando-se decisões emblemáticas do Primeiro JCRIM do TJMA envolvendo a pornografia de vingança, à luz da abordagem transdisciplinar de gênero proposta no artigo.

No tocante às fontes pesquisadas, pesquisaram-se livros e artigos afetos à temática da violência, legislações específicas como a Lei Maria da Penha, Código Penal, Código Civil, e Lei Carolina Dieckmann. Além desses materiais, foram explorados estudos da Organização Mundial da Saúde, Instituto Patrícia Galvão e Instituto de Pesquisa Aplicada, todos elaborados entre os anos de 2013 e 2017. Consultaram-se também materiais em endereços eletrônicos, como links de publicações do Conselho Nacional de Pesquisa e Pós-Graduação em Direito (Conpedi), Google Acadêmico, além de bases de dados online como Hei online e Vlex.

Quanto às decisões oriundas de tribunais superiores e de outros estados fora do Maranhão, realizaram-se buscas no indexador de decisões jusbrasil, mecanismo que permite o acesso a decisões de tribunais localizados em todo o país. Tanto no que se refere às decisões utilizadas como no que se refere ao material consultado online, utilizaram-se como buscadores as seguintes palavras-chave: pornografia de vingança, revenge porn, exposição da intimidade na internet, fotos/vídeos íntimos, violência de gênero, violência psicológica na internet e violência moral na internet. 


\section{A PORNOGRAFIA DE VINGANÇA ENQUANTO MANIFESTAÇÃO DA VIOLENCIA SIMBÓLICA NAS RELAÇÕES E INTERAÇÕES HUMANAS MODERNAS}

A divulgação não autorizada de conteúdo íntimo feminino como forma de represália ante o fim de relacionamentos tem implicado em desdobramentos que demandam a adoção de abordagens transdisciplinares para sua compreensão e devido enfrentamento, o que infelizmente ainda se observa de modo raro nas práticas jurídicas dedicadas ao tratamento desse crime.

Embora sua incidência seja crescente, em especial nos últimos anos, a pornografia de vingança surgiu ainda na década de 1980, antes mesmo da democratização da internet, conforme pontua Tsoulis-Reay (2013). De acordo com os estudos da Autora, essa prática nasceu associada a revistas eróticas masculinas norteamericanas que disponibilizavam seções para publicação de material encaminhado pelos leitores. Nesse contexto observava-se a clara associação entre ex-companheiras de leitores e profissionais do sexo, haja vista a vinculação de informações pessoais daquelas como nomes, fotos e contatos vinculados a ofertas de serviços de prostituição.

Sendo catalogada pelo Urban Dictionary no ano de $2007^{3}$, a expressão "pornografa de vingança" passou, a partir de então, a denominar a transposição forçada da intimidade feminina para os olhares públicos através do compartilhamento de fotos, mensagens ou vídeos de conteúdo sexual, como forma de causar o constrangimento das vítimas ou de obter lucros, principais motivações envolvidas.

Considerando a tradução do referido Dicionário e a necessidade de orientar a produção legislativa norteamericana acerca da matéria, a Professora de Direito da Universidade de Miami, Mary Anne Franks (2015), pontuou que a expressão pornografia de vingança pode ser compreendida como pornografia não consensual, compreendendo a divulgação de conteúdo sexual explícito das vítimas sem o consentimento dessas e com a finalidade de proporcionar-lhes constrangimentos e humilhações.

Compulsando as impropriedades semânticas da expressão, a estudiosa afirma que existe uma atecnia na combinação dos termos linguísticos "pornografia" e "vingança", tendo em vista que o ato de produzir conteúdo de cunho sexual, seja registrando momentos da sua intimidade ou permitindo que alguém o faça, não equivale à permissão para divulgação de tal conteúdo enquanto forma de entretenimento público, ou pornografia. Por esse motivo, discute-se gradativamente a pertinência de adotar-se a expressão "pornografia não consensual" em

${ }^{3}$ Dicionário de gírias e frases em inglês. Disponível em:< http://www.urbandictionary.com/>. Acesso em 20 set 2018 
substituição a "pornografia de vingança" (FRANK, 2015).

Aproveitando-se da confiança depositada por suas vítimas, materializada através do compartilhamento de conteúdo sexual ou na permissão para registro de momentos íntimos, os agressores frequentemente utilizam esse material obtido como subsídios para o estabelecimento de ameaças. Essa coerção psicológica é comumente utilizada para forçar a continuidade de relacionamentos abusivos, para fazer a vítima desistir de eventuais denúncias de violências e para a prática de chantagem, de modo a manter o alvo, preponderantemente do sexo feminino, sob controle constante.

Considerando as facilidades de circulação das informações via internet, os agressores normalmente utilizam uma infinidade de mecanismos para expor a sexualidade das vítimas, como, por exemplo, envio de emails, postagens em redes sociais, encaminhamento do material para sites eróticos de hospedagem nacional ou internacional, gravações do conteúdo em CD's/ DVD's/pen drives, impressões de fotos e capturas de tela, entre outros. Dessa forma, a publicação não consentida da intimidade é prática de baixo custo para os agressores e hábil no sentido de provocar o sofrimento intenso das vítimas ante a rápida disseminação do material com conteúdo sexual e alto impacto que costuma causar nessas e na sociedade.

Não se contentando com a divulgação não autorizada da sexualidade alheia, os agressores ainda se utilizam de estratégias diversificadas para intensificar o sofrimento emocional das vítimas, aumentando exponencialmente a intensidade da exposição e a vulnerabilidade dessas à perseguição de terceiros. Para tanto, normalmente adota-se a prática de vinculação de informações pessoais das vítimas junto com as imagens ou vídeos divulgados, como por exemplo, nomes, endereços residenciais e/ou profissionais, além de contatos de telefone e perfis de redes sociais (LENHART, 2013).

Desse modo, pontua-se que, não obstante as variações observadas quanto aos meios utilizados para obtenção e divulgação do conteúdo íntimo, bem como as motivações associadas ao crime, os resultados tendem a convergir para o sofrimento emocional intenso que fragiliza a saúde das vítimas de um modo geral. As consequências destrutivas desse crime são ainda mais acentuadas quando esse é praticado no contexto de um relacionamento afetivo, considerando-se que nesses casos a decepção e o desespero comumente observados nos rompimentos amorosos somam-se ao sentimento de humilhação.

Tal sofrimento se impõe na medida em que o comportamento das vítimas em sua vida privada, esfera pessoal por excelência e caracterizada pela possibilidade de desprendimento quanto à rigidez dos padrões sociais, é transposto abruptamente para o entretenimento público, que por sua vez é permeado por práticas discriminatórias e julgamentos com base em diferenciações de gêneros, não obstante a vigência dos discursos de 
autonomia sobre o corpo no contexto das sociedades modernas.

Caracterizando melhor os contornos dessa transposição, Faria et. Al (2015) destaca que esse espaço público que transforma a divulgação não autorizada da sexualidade feminina em divertimento se contrapõe totalmente ao espaço privado, que é naturalmente acolhedor, sendo marcado, em vez disso, pela visibilidade ampla, descontrolada e desprestigiada. Nessa perspectiva, Frank (2015) pontua que o uso do vocábulo "pornografia" na expressão pornografia de vingança sugere o deslocamento de cenas comuns na vida privada para o grande público da internet, que o transforma em entretenimento com rapidez e intensidade assustadoras.

Desse modo, o crime de pornografia de vingança, acompanhado de suas peculiaridades e repercussões no espaço público, demonstra a clara persistência das diferenciações de gênero no inconsciente coletivo do século XXI, não obstante a afirmação de discursos afetos à autonomia das pessoas sobre seus próprios corpos, direito supostamente garantido, em especial, às mulheres. Conforme observam Cavalcanti e Lelis (2016), embora essa nova modalidade de violência não seja praticada apenas contra mulheres, é perpetrada especialmente em face dessas, evidenciando assim que as distinções de papéis sociais entre os sexos subsistem, principalmente no tocante ao exercício da sexualidade feminina, para o qual ainda vigoram regras sociais rígidas e castradoras.

Descortinando-se o uso crescente da violência simbólica, principalmente em relações afetivas observadas nas sociedades contemporâneas, Faria et. al. (2015) pontua ainda que tal raciocínio é claramente aplicável na análise da pornografia de vingança, considerando que a supressão dos direitos à intimidade e autonomia sobre o próprio corpo constituem símbolos entrelaçados nessa trama complexa de violência contra a mulher.

Aprofundando a discussão em torno da violência de gênero exercida contra a mulher em um contexto de relações afetivas e mediante o recurso a um poder simbólico, o sociólogo francês Bourdieu (2001) pontua que esse tipo de agressão é caracterizado pela preponderância das coações morais e psicológicos sob suas vítimas. Fundada na fabricação de crenças que imprimem em vítimas e agressores a percepção esboçada nos discursos dominantes, a violência simbólica é alimentada no bojo dos processos culturais (BORDIEU, 2001).

Entre os ordenamentos jurídicos que mais se atentaram à violência simbólica que normalmente se associa às diferenciações de gênero, o direito argentino estabeleceu proibição expressa desse tipo de agressão psicológica e moral contra as mulheres na Lei 26.48516/09, intitulada Ley de Protección Integral para Prevenir, Sancionar, y Erradicar la Violencia Contra las Mujeres en los Ámbitos en que Desarrollen sus Relaciones Interpersonales.

Conjugando os julgamentos sociais negativos, os sentimentos de culpa e humilhação impostos às vítimas, bem como a externalização do poder simbólico exercido pelo agressor, a exposição da intimidade feminina conduz irreversivelmente ao escândalo público, que alimenta o constrangimento pessoal da mulher 
agredida.

Nesse sentido, existem variados elementos igualmente importantes para a compreensão dos julgamentos de reprovação social tecidos contra as vítimas, bem como no que diz respeito à compreensão da naturalização da conduta do agressor. Componentes psicosócioculturais introjetados, inclusive pelos operadores do direito, favorecem a inversão dos papéis entre vítimas e agressores quando se está diante da violência de gênero, em especial da pornografia de vingança.

Nessa discussão, Sibilia (2015) pontua que a exposição do corpo observada em larga escala nos dias atuais se distancia sensivelmente daquela sujeita à moralidade característica dos séculos XIX e XX. Sendo frequentemente utilizada sob a forma de recurso político, como por exemplo, em protestos que afirmam os direitos humanos, essa nudez feminina contemporânea assume o caráter de naturalidade por conta da sintonia existente entre leis e moral, relação que normaliza significativamente as subjetividades construídas ante a exposição de corpos.

Entretanto, essa mesma normalidade presente na disposição da intimidade nos espaços públicos modernos não é observada nas reações sociais ante a pornografia de vingança, para a qual são muito mais recorrentes as repercussões negativas envolvendo pudores e posicionamentos sexistas do que percepções afirmando a naturalidade da conduta.

Diante desse fato, Faria et. al. (2015) questiona os reais motivos que explicam tal contradição, argumentando que a moralidade presente no século XXI implica em efeitos diferenciados quando em contato com as tecnologias de comunicação. Desse modo, apesar de nudez ser tolerada nos dias atuais, a exibição da intimidade feminina ainda é tratada como tabu em circunstâncias de pornografia de vingança, gerando assim inquestionáveis repercussões negativas para as vítimas.

Nesse sentido, Silva e Silva e Manso (2017) destacam a essência da internet enquanto laboratório social sensível à construção e desconstrução da realidade, sendo assim um espaço aberto para a expressão de novas representações quanto ao reconhecimento das diversidades. Considerando que a cultura patriarcal observada sob o ponto de vista presencial contamina sensivelmente as redes de comunicação mediadas pelo uso das novas tecnologias, constitui desafio político a instrumentalização de identidades que permitam introduzir nessas redes contrapoderes capazes de enfrentar o sistema de dominação social vigente.

\section{A INCOMPRENSÃO DA PORNOGRAFIA DE VINGANÇA E DE SUA NATUREZA DE VIOLÊNCIA DE GÊNERO PELOS OPERADORES DO DIREITO}


Não obstante a vigência de um discurso político que se coaduna com a hipersexualização do corpo feminino, a sexualidade das jovens nunca foi tão controlada e disciplinada tal como é nos dias atuais. Isso é claramente observado a partir das soluções moralistas presentes nos discursos sociais majoritários relacionados à pornografia de vingança, que destacam a importância do retorno à virgindade e inocência femininas como principal forma de evitar a ocorrência desse problema (RENOLD; RINGROSE, 2012).

Nesse sentido, da Silva e Silva e Manso (2016) chamam a atenção para a falácia relacionada à liberdade na internet, considerando-se que essa se assemelha à liberdade já observada nos espaços presenciais, onde se observa a produção e reprodução dos sujeitos a partir de uma ideologia patriarcal que os sujeita ao constante controle por parte das instituições e tecnologias do poder.

Ante tamanha repercussão negativa do comportamento das mulheres cuja intimidade foi exposta na internet, a sensação de culpa é profundamente experimentada por essas, condenadas por si próprias e pelos outros por serem as mulheres que, de forma ousada, partilharam a sua intimidade e, além disso, escolheram erroneamente alguém não confiável para desfrutar do status de seu companheiro.

A fomentação desse sentimento de culpa no interior das vítimas é, pois, um indicativo adicional forte de ocorrência de violência de gênero, tendo em vista que esse surge simultaneamente como reflexo e como catalisador das lesões psicológicas evidenciadas, ocasionando um consequente agravante desse tipo de crime, o castigo psicológico que a vítima se impõe emocionalmente (FERNANDES, 2015).

Nessa discussão, Meneses e Cavalcanti (2016) pontuam as percepções incutidas nos julgamentos sociais negativos tecidos em torno da postura da vítima, que "se expôs demais" e "confiou demais no seu parceiro". Observa-se que tais construções atenuam a gravidade e naturalizam a agressão grave perpetrada pelo homem, que, sendo partícipe do contexto, expôs a sexualidade de sua parceira para um número indeterminando de pessoas, sujeitando-a assim a consequências extremamente destrutivas.

Aprofundando o debate em torno do caráter de violência de gênero observado na pornografia de vingança, Lins (2014) pontua que essa conduta se apresenta como forma de perpertuar discriminações e violências contra as mulheres, tendo em vista que a disseminação do conteúdo íntimo feminino será irreversivelmente seguida de um linchamento moral tendente a condenar a postura das vítimas. Diante de todo o exposto, observa-se a correspondência entre pornografia de vingança e violência de gênero, manifestada especialmente em forma de violência psicológica e ou moral contra a mulher.

Essa correlação entre o crime estudado e a violência de gênero é observada de forma clara na Lei Maria da Penha, principal instrumento de enfrentamento do problema no Brasil. Conforme o art. 5o dessa Lei, a violência doméstica e familiar contra a mulher consiste em ações ou omissões baseada no gênero que causem 
morte, lesão, sofrimento físico, sexual ou psicológico e dano moral ou patrimonial, constituindo forma de violação de direitos humanos.

Complementarmente, tendo em vista a complexidade de tal delito, observa-se que as consequências vivenciadas pela exposição da sexualidade feminina em ambiente virtual comprometem significativamente a integridade psicológica e física da mulher, possuindo clara configuração de violência de gênero, em geral de cunho intrafamiliar, sendo o comportamento do agressor deliberado e consciente, logo, também previsto de forma literal na Lei no 13.104/2015, conhecida popularmente como Lei do Feminicídio.

Essa lei empresta elevado destaque ao fenômeno da violência de gênero, evidenciando a faceta mais extrema desse tipo de violação dos direitos humanos, tipificando-a como homicídio qualificado, ou crime contra a vida. Na Lei do Feminicídio, a tipificação penal criminaliza o assassinato de mulheres motivado pelas questões de gênero, ou naturalização das diferenças de papéis sociais atribuídos a ambos os sexos, conforme o exposto no $\llbracket 2^{\circ}=$ A da norma.

Aprofundando essa discussão no tocante ao cabimento da aplicação da referida lei à complexidade da pornografia de vingança, Fernandes (2016) pontua que a essência de violência de gênero do fenômeno é evidente, tendo em vista que, a vingança masculina ante o fim de relacionamentos constitui a principal motivação para prática do delito. Insatisfeito, o homem espera vingar-se da vítima assegurando que essa seja condenada socialmente por recusar-se a lhe pertencer.

Mais do que uma ofensa, a pornografia de vingança conduz à morte das mulheres em plena vida, tendo em vista que os assassinatos virtuais, quando não desembocam em suicídios, implicam em consequências que perduram por tempo indeterminado. Entre essas anomalias implicadas à vida das vítimas, destacam-se as graves sequelas físicas e emocionais causadas às mulheres e a imposição permanente do constrangimento e isolamento a essas.

Considerando a multiplicidade de agentes que desenvolvem a conduta de divulgar e ou compartilhar um conteúdo que causa profundo sofrimento a alguém, o assassinato simbólico de mulheres através das redes sociais torna-se de alto potencial de dano, haja vista a participação de infinitos sujeitos, que assumem status de feminicidas virtuais (FERNANDES, 2016).

Cumpre observar ainda que a pornografia de vingança frequentemente conduz ao suicídio, mantendo clara correlação com crimes tipificados pelo Código Penal brasileiro afetos ao induzimento, instigação e auxílio ao suicídio, previstos no art. 122 da referida norma. Dessa forma, embora a conduta de suicidar-se não seja punível pelo direito, comete crime quem fornece embasamento emocional ou material para que outrem tire a sua vida.

Consoante o estabelecido no dispositivo, constituem causas de aumento de pena relacionadas à prática 
desses crimes o motivo egoístico e a capacidade de resistência diminuída das vítimas. Apesar da ampla visibilidade da pornografia da vingança no Brasil, e de sua natureza de violência de gênero, especialmente nos últimos anos em razão de suicídios fartamente noticiados pela imprensa, infelizmente ainda há muitas dúvidas e falhas quanto à aplicação da legislação afeta aos casos concretos.

Sob a perspectiva do direito civil, o entendimento jurisprudencial brasileiro tem apontado majoritariamente para o raciocínio de que pornografia da vingança fere a intimidade, a vida privada e a honra, ensejando a obrigação de indenizar por dano moral, argumentação que ofusca a gravidade do crime em apreço ante a ausência de proteção à integridade física ou psicológica da vítima, entendida, do ponto de vista científico, como integridade de sua saúde.

$\mathrm{Na}$ perspectiva criminal, o delito tem sido enfrentado mediante a tipificação enquanto injúria e difamação, crimes contra honra estabelecidos nos art. 139 e 140 do Código Penal. Desse modo, não se observa a criminalização dos variados males provocados à saúde das vítimas. Passíveis de enquadramento conforme o art. 129 do Código Penal, que tipifica a perpetração de lesões corporais, esses advêm da violência psicológica e ou moral agudas ou cronificadas, agressões inerentes aos casos de pornografia de vingança.

Considerando a significação da pornografia de vingança no discurso jurídico majoritário enquanto como crime contra a honra, desconectado do conceito de violência de gênero, observa-se total ausência de compreensão do delito enquanto outros tipos penais descritos por Fernandes (2015), contextualizados com a violência contra a mulher, tais como constrangimento ilegal (art. 146 CP), ameaça (art. 147 CP) e extorsão (art. 158 CP).

Nessa perspectiva, a problemática central da discussão não consiste na ausência de preenchimento legal para enquadramento da pornografia da vingança, enquanto manifestação de violência psicológica, na Lei Maria da Penha, considerando que uma parte expressiva dos casos acontece em razão de relação de afeto preexistente entre as partes.

A principal explicação para tal entendimento limitado é a falta de compreensão da essência da pornografia da vingança enquanto lesão ou violência à saúde psicológica da vítima, percepção que ainda não é comumente observada em peças jurídicas produzidas por advogados, membros do Ministério Público e Poder Judiciário.

Aprofundando esse debate, Santos (1996) destaca que a formação legalista e simplista dos profissionais de Direito brasileiros explica a imperícia desses para a devida compreensão e consequente enfrentamento da complexidade que permeia os conflitos sociais trazidos à demanda do Sistema de Justiça. Na melhor das hipóteses a prática jurídica brasileira continua ancorada quase que exclusivamente no determinismo, positivismo e racionalismo científico, bases teóricas que, tomadas de modo isolado, não dão conta dos paradigmas afetos aos 
conflitos contemporâneos.

Apoiando-se predominantemente no referencial jurídico-dogmático, esse instrumental teórico se funda na eliminação de conhecimentos científicos extra normativos no momento de aplicação das normas, na separação entre o Direito e suas finalidades sociais e na limitação dos problemas jurídicos aos autos do processo, sem atenção à ligação desses com a realidade (SANTOS, 1996).

Nessa perspectiva, Fernandes (2015) analisa as consequências da formação deficiente dos operadores do Direito para o enfrentamento da violência de gênero, destacando a revitimização secundária e ou a ocorrência da violência institucional, modalidade de violência de gênero originada da imperícia de quem possui o dever jurídico de proteger.

\section{A INDISTINÇÃO ENTRE AS VIOLENCIAS DE GENERO PRATICADAS EM CIRCUNSTÂNCIAS PRESENCIAIS E VIRTUAIS}

Atentando-se à gravidade das dimensões potencialmente atingidas pela exposição não autorizada da sexualidade feminina na internet, Frank (2015) observa que em um intervalo temporal curto de dias, o conteúdo íntimo pode ocupar as primeiras páginas do mecanismo de pesquisa do google, indicando também, entre os resultados, informações pessoais das vítimas.

Assim, observa-se a potencialidade intensa de dano desse constrangimento no sentido de alcançar, além das vítimas, pessoas próximas dessas como familiares, empregadores e amigos. Considerando-se a vulnerabilidade das mulheres vítimas de pornografia de vingança, entendida como violência de gênero intrafamiliar, por manterem ou haverem mantido relacionamento afetivo com seus agressores, essas frequentemente vivenciam episódios de cyberbullying, assédios, despedidas de empregos, pressões para mudança de endereço e de escola, além de instigação ao suicídio (FRANK, 2015).

Tal contextualização demonstra assim o poder lesivo, cruel e violento da pornografia de vingança, apta para causar desequilíbrios à integridade corporal das vítimas mediante lesões em sua saúde psicológica, materializáveis e periciáveis em forma de depressão, ansiedade e tendências ao suicídio, como ocorreu com duas jovens brasileiras cujos casos de suicídio foram amplamente divulgados pela imprensa ${ }^{4}$. No desdobramento dessa conduta criminosa, as peculiaridades do ciberespaço intensificam assustadoramente o poder destrutivo oriundo da exposição sofrida pelas vítimas.

\footnotetext{
${ }^{4}$ CARVALHO, Bruna. "Me senti impotente e com nojo", diz estudante que teve fotos íntimas vazadas". Carta Capital: Ideias em Tempo Real. 29/11/2013. Disponível em: <https://www.cartacapital.com.br/sociedade/me-senti-impotente-e-com-nojo-dizestudante-que-teve-fotos-intimas-vazadas-3974.html>. Acesso em 13 set 2017.
} 
Nessa discussão, merece especial destaque o suicídio da jovem italiana Tiziana Cantone, de 31 anos, que ficou conhecida mundialmente por conta da ampla repercussão da sua exposição íntima nas redes sociais ${ }^{5}$. Após ter a sexualidade divulgada na internet, a vítima tornou-se alvo de piadas e abusos, sendo forçada a mudar de endereço e modificar o seu nome na tentativa superar o extremo constrangimento causado pela exposição íntima.

Apesar desssas medidas adotadas pela vítima, o conteúdo continuou sendo compartilhado com alta intensidade, de forma que frases ditas pela jovem em um contexto de intimidade originaram imagens e vídeos humorísticos (memes), além de estampas de camisetas e objetos como canecas.

Antes de cometer o suicídio, a vítima havia conseguido provimento jurisdicional que ordenou a retirada do vídeo do ar em diversos sites, mas foi determinado também que a jovem pagasse uma quantia de aproximadamente 20 mil euros a título de custas processuais, fato caracterizado pela mídia de "insulto final". Após o suicício, o enterro da jovem foi transmitido ao vivo por meios de comunicação italianos, havendo, desse modo, a repercussão internacional da tragédia de quem gostaria apenas de ter sua vida pessoal esquecida.

Ante a insignificância das barreiras geográficas, a intimidade forçosamente exibida é potencialmente compartilhada com pessoas de várias nações de forma simultânea e por causa da irrelevância das barreiras temporais, a exposição se repete a cada acesso do conteúdo.

Constituindo ambiente fértil para o estabelecimento de relações interpessoais, com um número de pessoas exponencialmente maior do que nos espaços presenciais, o ciberespaço pressupõe especial importância dos meios de comunicação, possuindo padrão de interatividade específico, caracterizando-se principalmente pela transponibilidade das fronteiras geográficas, culturais e socais (BAUMAN, 1999).

Apesar de todas as facilidades possibilitadas pela ampla interatividade trazida pela globalização e instrumentalizada pelo ciberespaço, também são observadas preocupações para os governos e cidadãos ante a variedade de mecanismos aptos para reafirmação dos discursos e práticas sociais desumanas já observadas no mundo presencial, como a violência de gênero, por exemplo.

Nesse sentido, estudo ${ }^{6}$ realizado pelo Instituto Avon revelou dados preocupantes relacionados à violência contra a mulher na internet, considerando que, entre o total de sujeitos pesquisados, $15 \%$ das mulheres passaram por situações em que um homem tentou registrá-las sem autorização através de fotos e vídeos.

A mesma pesquisa apontou que, ao fim do relacionamento, $51 \%$ das mulheres entrevistadas sofreram

5 UOL NOTÍCIAS. Suicídio de vítima de 'pornô de vingança' choca a Itália. Disponível em:< https://noticias.uol.com.br/ultimas-noticias/bbc/2016/09/16/suicidio-de-vitima-de-porno-de-vinganca-choca-a-italia.htm>. Acesso em 24 jun 2017.

${ }^{6}$ A pesquisa compreendeu jovens de ambos sexos, entre as idades de 16 a 24 anos, abrangendo as 5 regiões do país, de 08 de novembro de 2014 a 13 de novembro de 2014, totalizando 2.046 entrevistados. Fonte: INSTITUTO AVON. Violência contra a 
com a divulgação de detalhes íntimos da relação pelo ex-companheiro. Por isso, 45 \% dessas pararam de usar redes sociais e/ou sentiram a necessidade de criar uma nova conta nessas a fim de minimizar danos emocionais e morais sofridos.

De acordo com as porcentagens acima, observa-se como a pornografia de vingança tem figurado no cotidiano das pessoas, constituindo realidade na vida de mais da metade do total de mulheres entrevistadas. Quanto ao compartilhamento de fotos íntimas de mulheres realizado por homens, $59 \%$ deles receberam materiais de pessoas desconhecidas, enquanto $41 \%$ desses receberam conteúdo íntimo de pessoas do seu convívio. Do total dos homens que receberam vídeos ou fotos íntimas de mulheres conhecidas ou não, 28\% repassaram esse conteúdo.

Considerando-se esses dados, observa-se o imenso poder de vazão das redes sociais na disseminação de conteúdos íntimos, que chegam facilmente a pessoas conhecidas e desconhecidas das vítimas sendo assim repassados em larga escala. Nesse ponto, merece destaque a porcentagem de 59\% de homens que receberam vídeos ou fotos íntimas de estranhas.

O mesmo levantamento indicou que $4 \%$ das mulheres entrevistadas sofreram ofensas públicas nas redes sociais e $2 \%$ receberam ameaças dos parceiros relacionadas à publicação de conteúdo íntimo nas redes sociais. Percebe-se assim o caráter de tortura psicológica inerente à pornografia de vingança. Essa prática é frequentemente utilizada como mecanismo dos agressores para forçar suas vítimas a adotar comportamentos não desejados por essas, como, por exemplo, enviar mais conteúdos íntimos, continuarem em relacionamentos abusivos e/ou praticarem atos sexuais.

Nesse sentido, merece destaque a decisão jurisdicional do juiz piauiense Luiz de Moura Correia, que determinou a primeira prisão brasileira levando-se em consideração a prática de estupro virtual. No caso concreto, o agressor alimentava um perfil falso no facebook, no qual ameaçava divulgar fotos íntimas da vítima caso essa se recusasse a enviar mais conteúdo sexual.

Entre as principais coações feitas sob a vítima, o agressor exigiu que essa enviasse fotos se masturbando e introduzindo objetos em sua genitália, conduta entendida pelo magistrado enquanto estupro, haja vista a coação moral irresistível forçando a prática de ato libidinoso pela ofendida?

\footnotetext{
mulher: o jovem está ligado? Disponível em: <http://agenciapatriciagalvao.org.br/wpcontent/uploads/2014/12/pesquisaAVON-violencia-jovens_versao02-12-2014.pdf>. Acesso em: 24 ago 2016.

7 Juiz do Piauí decreta primeira prisão por estupro virtual no Brasil. Jus Brasil. Disponível em:< https:// correcaofgts.jusbrasil.com.br/noticias/485902382/juiz-do-piaui-decreta-primeira-prisao-por-estupro-virtual-no-brasil>. Acesso em 23 set 2017.
} 
Outro documento ${ }^{8}$ importante para compreensão da violência de gênero no ciberespaço é o relatório Vozes dos Espaços Digitais: Violência contra a Mulher Relacionada à Tecnologia'. De acordo com o referido estudo, as diferentes tecnologias da informação (TIS) podem ser potencialmente usadas para perpetrar a violência de gênero de várias maneiras. Nessa discussão os agressores normalmente utilizam telefones móveis e internet para seguir, molestar e vigiar os movimentos e atividades das mulheres, podendo fazer uso especial dos serviços de localização e/ou vigilância das mensagens e chamadas recebidas.

Outra forma de violentar as mulheres através das tecnologias da informação também destacada pelo Relatório é a distribuição de fotos e gravações de conteúdo sexual, prática associada ao cybermolestamento, ou perseguição on line, violência doméstica e estupro. Acrescenta-se também o uso das novas tecnologias pelos agressores quando esses desejam atrair as vítimas para situações de abuso sexual, adotando-se para tanto avisos ou mensagens dissimuladas na internet.

Diante de todo o exposto, o relatório conclui que a tecnologia pode ser utilizada pelos agressores como forma de perpetrar variadas modalidades de agressões e de dar continuidade à cultura de violência contra a mulher já observada no mundo presencial, concorrendo para a naturalização e justificação de toda sorte de violência de gênero.

Muitos dos veículos tecnológicos viabilizam o cometimento da violência de gênero de forma anônima e impune, considerando que ainda não existe, na maior parte dos países, um enfrentamento jurídico condizente com a complexidade dos crimes virtuais e com os danos causados por esses às vítimas.

Contextualizando essa discussão especialmente no que concerne a divulgação não autorizada de conteúdo íntimo feminino na internet, o relatório destaca a gravidade da conduta, tendo em vista que, em tempos marcados pelo brocardo "tudo se registra, nada se esquece", as possibilidades de registro e reprodução do conteúdo íntimo são infinitas, implicando no sentimento de completa impotência das vítimas ante a continuidade delitiva e multiplicação de agressores a cada compartilhamento.

Aprofundando o debate em torno dos abusos praticados on line, o relatório acrescenta ainda que a perseguição nas redes, motivada pela violência de gênero, costuma envolver vários abusadores, entre aqueles que

\footnotetext{
${ }^{8}$ Este informe apoia-se nas experiências e achados do projeto ODM3: Dominemos a tecnologia! - da Associação para o Progresso das Comunicações (APC). Este projeto trabalhou com organizações de direitos das mulheres de doze países da África, Ásia e América Latina entre 2009 e 2011 e ofereceu apoio a estas organizações para que investigassem e respondessem à violência relacionada com a tecnologia, e fortalecessem sua capacidade para usar ferramentas TIC em suas respostas à violência. $\mathrm{O}$ informe baseia-se também em outros trabalhos do Programa de Apoio às Redes de Mulheres (PARM) da APC na área de VCM, direitos das mulheres, direitos sexuais e $\quad$ TICs. http://www.genderit.org/sites/default/upload/38_violenciacontramulher_politics12.pdf.

9 PROGRAMA DE APOIO A REDES DE MULHERES DA ASSOCIAÇÃO PARA O PROGRESSO DAS COMUNICAÇÕES. Vozes dos espaços digitais: violência contra a mulher relacionada à tecnologia. Disponível em:< http://www.genderit.org/sites/default/upload/38_violenciacontramulher_politics12.pdf $>$. Acesso em 12 mai 2017.
} 
originalmente publicam o material e aqueles que facilitam a sua divulgação. Desse modo, observa-se uma violação grave aos direitos de autonomia e privacidade das mulheres, além da completa vulnerabilização da sua saúde psicológica.

Não obstante essa aparente nuança de novidade do ciberespaço, é importante observar que as relações humanas mantidas em sua vigência não perdem substancialmente as características externalizadas na convivência presencial, senão conservam muitas delas, sendo possível haver a sua intensificação. Portanto, a diferença efetiva entre relações e interações humanas está apenas em serem virtuais ou presenciais, sendo ambas inteiramente reais e sobrepostas.

Considerando a natureza dessa interação, não existem distinções sólidas entre a realidade e a representação simbólica, tendo em vista que a construção de uma virtualidade se apresenta como um dos frutos da operação entre o real e o virtual (CASTELS, 1999). Reforçando esse ponto de vista no sentido de que as relações humanas mantidas no ciberespaço não se apartam inteiramente das interações observadas do ponto de vista presencial, Lévy (2008) afirma que entre as duas esferas existe complementariedade.

Aprofundando os termos dessa discussão, Manso e da Silva e Silva (2017) pontuam que os cenários virtuais não constituem a negação do regime de binarismos observado na realidade social, senão um anexo perfeito dessas, haja vista as cyberestruturas que conferem continuidade às diferenciações observadas do ponto de vista presencial.

Acaso los escenarios virtuales que recrean la sociedad no son el mantenimiento del régimen binario, cuya escritura es el gender?Los mundos virtuales son el anexo perfecto de la realidad social, espacios de comunicación que hacen de continuum, que mantienen las estructuras y supraestructuras sociales casi intactas, la libertad y el desenfreno que en ellos se puede vivir como "ser sujeto no real" son un mero espejismo, una ilusión, un intento por vivir una vida no vivida pero sí deseada ( da SILVA e SILVA; MANSO, 2017, p. 278).

Tamanha conjuntura de fluidez de informações, imagens e comunicação, bem como a confusão de identidades entre o virtual e o presencial, agravam consideravelmente os efeitos dos crimes virtuais sobre as vítimas. Tal raciocínio é perfeitamente aplicável à complexidade da disseminação não autorizada de conteúdo íntimo na internet.

Nesses casos, a combinação entre o poder de vazão assustador das redes, as dificuldades de restrição do material objeto do crime, bem como os mecanismos repressivos insipientes na maior parte dos ordenamentos jurídicos ocidentais, contribuem para a falta de controle sobre a exposição, implicando assim no sofrimento emocional intenso das vítimas. Essas dificuldades de enfrentamento dos crimes praticados utilizando-se as ferramentas da internet relacionam-se consideravelmente com a arquitetura inerente a esse novo ambiente relacional.

Nesse sentido, a arquitetura das redes teorizada por Castels (1999) e observada no contexto relacional 
da internet confere significados inéditos a elementos muito bem delimitados do ponto de vista presencial, como tempo e espaço. Na sociabilidade observada do ponto de vista virtual, esses fatores estão dissociados das limitações físicas auferidas pelos sentidos humanos.

Nessa perspectiva, não obstante as características que permitem a parcial diferenciação entre as violências praticadas em circunstâncias presenciais e virtuais, essas em grande medida decorrentes da presença ou ausência de barreiras temporais e espaciais, não existe uma distinção sólida entre elas, haja vista que são inteiramente reais e sobrepostas.

Ante a aptidão de ambos os meios para a afirmação de discursos baseados em diferenciações de gênero e agressões físicas e/ou psicológicas fundadas nessas, acrescenta-se que o único critério para a distinção dessas é a intensidade e o poder destrutivo das mesmas, considerando que no ciberespaço esses elementos se mostram absurdamente pronunciados comparativamente aos observados nos espaços presenciais.

\section{A INCONSISTENCIA DA TIPIFICAÇÃO MAJORITÁRIA DA PORNOGRAFIA DE VINGANÇA NO BRASIL E SUAS DISTORSÕES QUANTO A FIXAÇÃO DA COMPETÊNCIA PROCESSUAL}

Conforme o entendimento jurídico majoritário, caracterizado pela superficialidade e abordagem limitada, a honra é o principal bem jurídico lesionado pelo crime de pornografia de vingança, tipificação que se revela equivocada à medida que compromete a percepção da amplitude e gravidade do fenômeno estudado.

A partir da eleição do Código Penal, enquanto disciplina normativa normalmente aplicada aos casos concretos observa-se lamentavelmente, que conceitos machistas e patriarcais introjetados e naturalizados, inclusive pelos julgadores, concorrem para a interpretação de que a vítima colaborou com a prática do ato. Sendo assim, mulheres cuja sexualidade foi exposta são consideradas corresponsáveis pelas consequências do delito, o que interfere diretamente na arbitragem dos danos morais, conforme se pode observar em decisão do TJMG.

APELAÇÃO CÍVEL - CORPO FEMININO - FOTOS DE PARTES INTIMAS -
DIVULGAÇÃO PELA INTERNET - AUTORIA INCERTA - DANOS MORAIS -
DEVER DE INDENIZAR - PARTICIPAÇÃO EFETIVA DA VÍTIMA -
INDENIZAÇÃO DIMINUÍDA [...]A postura de quem fragiliza o conceito de moral pode
autorizar avaliação condizente com essa postura[...]Vítima que participa de forma efetiva e
preponderante para a consumação do fato tem de ser levado em consideração na fixação da
condenação (grifos nossos).BRASIL. Tribunal de Justiça do Estado de Minas Gerais. $16^{a}$
Câmara Cível. Apelação Cível no $1.0701 .09 .250262-7 / 001$. Relator: José Marcos Rodrigues
Vieira Julgado em 23/07/2015. Disponível em:<http://www.truzzi.com.br/blog/wp-
content/uploads/2014/07/Juris_Revenge-Porn_TJMG_culpa-concorrente-vitima.pdf>.
Acesso em 08 jul 2017.

Diante do exposto, observa-se que nem mesmo as decisões jurídicas estão a salvo de espelharem concepções machistas e estereótipos culturais sexistas, o que explica a contaminação do Direito por julgamentos 
mais morais que bioéticos, carentes de parâmetros científicos transdisciplinares. Essa transposição iatrogênica e tecnicamente hipossuficiente de valores culturais ou pessoais projetados nas peças judiciais fragiliza consideravelmente a proteção das vítimas nesses casos, potencializando os danos a elas já causados e configurando uma segunda ordem de violência tão ou mais grave e cruel que a primeira: a institucional.

Desse modo, observa-se a superficialidade do entendimento majoritário, haja vista o enquadramento estrito da pornografia da vingança apenas como crime contra a honra, deixando-se de dar a devida atenção às lesões à saúde psicológica e à integridade física da vítima, dimensões pessoais irreversivelmente abaladas ante a conduta criminosa em estudo.

Nessa perspectiva, a disciplina do Código Penal brasileiro, elaborado na década de 1941, não se mostra apta a regular as violências de gênero praticadas na internet, seja pela ausência da percepção dessas enquanto crime de gênero, seja por não dar conta da complexidade das novas problemáticas sociais.

Além da tipificação da pornografia da vingança enquanto crime contra a honra observa-se também nas práticas jurídicas a tipificação da conduta no rol dos crimes cibernéticos, previstos na Lei 12. 737/2012, popularmente conhecida como Lei Carolina Dieckmann.

Esse diploma legislativo foi promulgado em um contexto de discussão acerca da garantia individual da intimidade ante aos perigos implicados pelo uso de dispositivos tecnológicos. A vítima, atriz Carolina Dieckmann, teve fotos íntimas roubadas por hackers, que não obtendo proveito econômico com as ameaças de publicação do material, divulgaram o conteúdo íntimo na internet.

No entanto, também é possível identificar fragilidades nos enunciados desse diploma legislativo, especialmente no tocante à definição de "dispositivo informático", não sistematizado de forma ampla e clara, considerando-se que há uma infinidade de dispositivos existentes capazes de armazenar dados sujeitos à violação. Da mesma forma, observam-se impropriedades na escolha do termo "invadir", que não abrange o ato de ter acesso a conteúdo íntimo sem invasão, como no caso de compartilhamentos não autorizados de vídeos e fotos pelo aplicativo whatsupp (SILVA; SILVA, 2014).

Em consequência do enquadramento estrito de que a exposição não autorizada da sexualidade feminina atenta apenas contra a honra, configurando crime de injúria e difamação e ou delito cibernético, a competência para conhecimento e julgamento do delito em estudo tem sido fixada majoritariamente nos Juizados Especiais Criminais.

Conforme o art. 61 da Lei 9099/99, que estabelece a criação dessas unidades jurisdicionais, os Juizados Especiais Criminais são competentes para o tratamento das infrações de menor potencial ofensivo, delitos cuja pena máxima não ultrapassa dois anos na capitulação do Código Penal. De acordo com essa regra, os crimes 
contra a honra fazem parte do rol de abrangência dos juizados, haja vista a pena máxima de seis meses de detenção para o crime de injúria (art. 140 CP) e três meses correspondente ao crime de difamação (art. 139 CP).

Além disso, o principal tipo de crime cibernético previsto pela Lei Carolina Dieckmann correspondente à pornografia de vingança também se sujeita à disciplina das referidas unidades jurisdicionais. Esse estabelece a pena máxima de um ano para a conduta de invadir dispositivo informático alheio, com o fim de obter dados sem autorização expressa ou tácita do titular do dispositivo (art. 154-A).

Essa associação entre juizados especiais e crimes de menor potencial ofensivo, considerados sob o ponto de vista jurídico, enquanto infrações penais dotadas de menor complexidade, contextualiza-se perfeitamente com as reformas institucionais brasileiras focadas no acesso à justiça.

Nessa perspectiva, Cappelletti (1988) observa que tais mecanismos têm sido largamente utilizados para reduzir os custos do processo ao Estado e às partes interessadas, proporcionando dessa forma o acesso rápido e viável para cidadãos em demandas cuja resolução demanda menor esforço jurídico.

Reformas dessa natureza consubstanciaram a seu tempo o objetivo político de fornecer mecanismos criativos, abrangentes e multifacetados aptos a reestruturar a máquina judiciária ante a multiplicação de processos e desafios quanto à efetividade no trato desses (CAPPELLETTI, 1988).

Conjugados com o objetivo de dar uma resposta mais ágil do judiciário aos crimes de menor potencial ofensivo, os princípios de funcionamento dos juizados especiais criminais, previstos no art. 62 da Lei 9099/95, preceituam a oralidade, informalidade, economia processual e celeridade.

Diante de todo o exposto, observam-se distorções gritantes quanto à fixação da competência para conhecimento e julgamento dos crimes envolvendo pornografia de vingança, considerando que esses constituem delitos complexos permeados por diferenciações de gênero, incompatíveis, portanto, com o modelo punitivo brasileiro correspondente aos crimes contra a honra.

Essas distorções são observadas principalmente quanto à concepção e tratamento equivocados das violências psicológicas e moral praticadas com o auxílio de mecanismos sofisticados, portanto mais hábeis a causar o sofrimento das vítimas, enquanto crimes de menor potencial ofensivo.

Além disso, os princípios que orientam o funcionamento dos juizados especiais criminais conduzem ao enxugamento dos processos e desafogamento da máquina judiciária, raciocínio que, aplicado ao tratamento da pornografia de vingança, implica no silenciamento da violência em nome da celeridade processual.

Observa-se ainda que a estrutura institucional simplista dos juizados especiais se apresenta totalmente incompatível com a finalidade de prevenir e erradicar a violência de gênero, seja pela ausência de previsão legislativa, seja pela carência de estratégias institucionais dedicadas ao problema. 


\section{ESTUDO DE CASOS QUE DEMONSTRAM A INCOMPATIBILIDADE DO MODELO PROCESSUAL DOS JUIZADOS CRIMINAIS PARA TRATAMENTO DA PORNOGRAFIA DE VINGANÇA}

As distorções entre o procedimento dos juizados especiais criminais, simplificado em essência, e a complexidade da violência de gênero intrafamiliar são claramente observadas mediante a análise de processos envolvendo pornografia da vingança que tramitam nessas instâncias, a partir dos quais é possível identificar o alto poder destrutivo do crime na vida das vítimas, concluindo-se assim que esse ultrapassa categoricamente a gravidade dos delitos de menor potencial ofensivo.

[...] Segundo a vítima A.S.W, teve conhecimento através de amigos que estava "circulando" nas redes sociais fotos íntimas suas. [...] Há aproximadamente 5 (cinco) anos, quando estava em um relacionamento com o Autor E.M.C, "tirou" algumas fotos suas enquanto estava despida; Que algum tempo depois, após o término do relacionamento, A.S.W questionou a E.M.C se já havia "apagado" [...]. Teve conhecimento ainda que os nacionais C.S.P e W.V.R "espalharam" as imagens [...] A vítima relata que teve prejuízo em sua imagem [...] A vítima relatou ainda que está sendo submetida a tratamento psicológico pelo abalo emocional que sofreu pela divulgação de sua intimidade [...]. ESTADO DO MARANHÃO. Secretaria de Segurança Pública. Delegacia de Polícia Civil. Superintendência Estadual de Investigações Criminais. Boletim de Ocorrência. Primeiro Juizado Especial Criminal. Processo 2222015. Juiz: Andrea Furtado Lago. Tramitação entre 16/04/15 e 08/10/2015.

Realizada transação penal

[...] TERMO DE AUDIÊNCIA. Aberta audiência, presente as partes com exceção do suposto autor W.V.R em razão de não ter sido intimado conforme Certidão de fls. 46. Tentada a Composição Civil esta não foi aceita pela Vítima que se manifestou no sentido de continuar com o feito até o final. Constatando o Conciliador, que os Autores do fato presentes, não possuem condenações criminais, Ihes foi Lançada a Proposta de Transação Penal na forma do que dispõe os Enunciados 70 e 71 do FONAJE, que foi aceita e encaminhada ao Ministério Público. Os Autores do fato comprometem-se a pagar ao Estado uma Multa Pecuniária de R $\$ 394,00$ (trezentos e noventa e quatro reais), cada um em duas parcelas de R\$192,00 cada com vencimento em até 16 de julho e 16 de agosto de 2015 [...] Em relação ao suposto Autor do fato W.V.R, fica designada audiência para o dia 02 de julho de 2015 às 10:15 na sala de audiências deste Juizado, saindo ciente a Vítima. [...] Sentença: Homologo por sentença, para que produza seus jurídicos e legais efeitos a Transação Penal efetuada entre os Autores do fato C.S.P e E.M.C e o Ministério Público nos termos acima. Ficam os Autores do fato ciente que a presente transação não implicará em antecedentes e que a única ressalva é que, por se tratar de um beneficio, não poderá ser usado novamente pelo prazo de 05 anos se os Autores voltarem à Justiça Criminal Especial. Em sendo assim, Declaro Extinta a Pretensa Punibilidade dos Autores citados acima do fato em relação a este processo, não havendo outros efeitos jurídicos penais. TRIBUNAL DE JUSTIÇA DO ESTADO DO MARANHÃO [...] Primeiro Juizado Especial Criminal. Processo 2222015. Juiz: Andrea Furtado Lago. Tramitação entre 16/04/15 e 08/10/2015.

TERMO DE AUDIÊNCIA [...] Iniciada audiência, presente o autor do fato W.V.R, 
acompanhado de seu advogado acima identificado. Presente a vítima A.S.W, acompanhada de seu advogado acima identificado. Tentada a composição civil entre as partes, esta não foi possível. Presente a representante do Ministério Público. Feita a proposta de transação penal, esta foi aceita pelo autor do fato. $\mathrm{O}$ autor do fato pagará o valor da prestação pecuniária o equivalente a metade de um salário mínimo, ou seja, R\$394,00 (trezentos e noventa e quatro reais), em uma única parcela com vencimento até o dia 20/09/2015. [...] Sentença: Vistos, etc. Homologo, por sentença, para que produza seus jurídicos e legais efeitos a proposta de Transação Penal aceita pelo autor do fato. Ressalte-se que tal reprimenda não importará em reincidência, sendo apenas registrado para impedir a concessão do mesmo beneficio no prazo de 5 (cinco) anos, não haverá anotação no livro "Rol dos Culpados" e nem importará em suspensão dos direitos políticos. Publicada em audiência, dou os presentes por intimados [...] Lido e achado conforme vai por todos assinado [...] TRIBUNAL DE JUSTIÇA DO ESTADO DO MARANHÃO [...] Primeiro Juizado Especial Criminal. Processo 2222015. Juiz: Andrea Furtado Lago. Tramitação entre $16 / 04 / 15$ e $08 / 10 / 2015$.

bserve-se que no primeiro caso supra evidenciado a vítima relatou à Autoridade Policial (vide Boletim de Ocorrência), a divulgação não autorizada de sua intimidade mediante a violação da confiança depositada no seu ex-companheiro, o que implicou em um desequilíbrio persistente da sua saúde psicológica.

Durante a fase processual, especialmente na audiência em que compareceram os responsáveis pela disseminação do conteúdo íntimo no caso concreto, observa-se a aplicação da transação penal, instituto jurídico do Direito Penal que exclui a aplicação de pena e a anotação do crime nos antecedentes criminais dos acusados, que, aceitando o benefício, devem apenas pagar multa para o Estado.

Conforme o auto, constatou-se que no dia 12/10/16 a vítima M.S.S vem sofrendo com difamação praticada pelo seu ex-namorado mediante mensagens de texto, chamadas telefônicas de desconhecidos e página do facebook na qual foram colocadas fotos pessoais da vítima [...].ESTADO DO MARANHÃO. Secretaria de Segurança Pública. Delegacia de Polícia Civil. Superintendência Estadual de Investigações Criminais. Carta Precatória. Primeiro Juizado Especial Criminal. Processo 7182016. Juiz: Andrea Furtado Lago. Tramitação entre 29/09/16 e 12/12/2016. Fls. 03/04.

[...] Trata-se de procedimento criminal instaurado contra o autor do fato E.C.G para apurar a prática do crime tipificado nos Art. 139 do CPB, em que figura como vítima M.S.S [...] DECIDO. Compulsando os autos, verifica-se que muito embora este Juizado Especial Criminal cumpra o seu papel na Prestação Jurisdicional em dar andamento do feito, constata-se que já não resta mais tempo hábil para que a vítima apresente a peça jurídica denominada Queixa-Crime. Por sua vez, ainda que se admitisse, em tese, a viabilidade de sanar a mácula, o transcurso do prazo decadencial de 06 (seis) meses, de qualquer sorte, obstaria tal desiderato, já que o fato se deu em 12/12/2015. Diante do exposto e considerando o transcurso do prazo para interposição da Peça Jurídica, DECLARO EXTINTA A PRETENSA PUNIBILIDADE do autor do $X$ em relação ao presente procedimento criminal em razão da Decadência (art. 107, Inc. IV do CPB). [...] TRIBUNAL DE JUSTIÇA DO ESTADO DO MARANHÃO. Primeiro Juizado Especial Criminal. Processo 7182016. Juiz: Manoel Matos de Araújo, magistrado respondendo pelo $1^{\circ}$ JECRIM. Tramitação entre 29/09/16 e 12/12/2016.

No segundo caso, a vítima relata a divulgação de suas fotos íntimas através de uma página do facebook alimentada pelo seu ex-namorado, crime caracterizado pela clara faceta de violência de gênero, haja vista a relação 
afetiva que existiu entre as partes.

Mais uma vez torna-se evidente a incompatibilidade entre o modelo processual dos juizados especiais criminais e a complexidade da pornografia de vingança, modalidade de violência psicológica silenciada em consequência do seu tratamento mediante os institutos despenalizadores típicos da Lei 9099/99.

Diante do exposto, a Lei Maria da Penha se apresenta enquanto o instrumento normativo mais coerente com a dimensão do crime em estudo, haja vista a fixação da competência na vara da mulher, na qual seria juridicamente possível o requerimento de medidas protetivas aptas a diminuir os dados causados.

Entre essas destacam-se a reeducação do agressor, avaliação psicossocial do mesmo, proibição de contatos entre esse e familiares da vítima e ou testemunhas através dos diversos meios de comunicação, proibição da continuidade de divulgação do material íntimo, entre outras.

\section{A EXPERIENCIA BRASILEIRA DE NEGLIGENCIA QUANTO AO ENFRENTAMENTO DA VIOLENCIA DE GENERO NOS JUIZADOS CRIMINAIS E SEU LEGADO AO TRATAMENTO DA PORNOGRAFIA DE VINGANÇA}

Atualmente os juizados especiais criminais não detém competência para conhecimento e julgamento de processos cujo objeto esteja relacionado com violência doméstica e familiar contra a mulher, haja vista a vedação expressa presente na Lei Maria da Penha, que fixa a competência desses crimes em varas especializadas dotadas de estrutura diferenciada visando atender a complexidade da violência de gênero.

No entanto, antes da promulgação da referida Lei, aos casos de violência contra mulher era aplicada a Lei 9099/95, implicando assim na tipificação desses delitos enquanto condutas de menor potencial ofensivo, enquadramento absurdo que gerou profundas discussões à época, em sua maioria apontando para o retrocesso no tocante à percepção e enfrentamento da violência de gênero.

Esclarecendo-se os contornos desse retrocesso para diversos segmentos da sociedade, Izumino (2003) pontua as vítimas eram possuidoras da faculdade de encerrar o processo através da renúncia dos seus direitos, evitando assim quaisquer consequências penais gravosas para os seus companheiros ou ex-companheiros sendo, portanto, colocadas em posição de elevada vulnerabilidade pelo sistema de justiça, haja vista as ameaças dos agressores para que as postulantes desistissem dos processos (IZUMINO, 2003).

Além disso, a aplicação de institutos despenalizadores revelou-se problemática para os casos envolvendo 
violência de gênero, tendo em vista que a conciliação e a exigência de representação da ofendida criaram um modelo penal que naturalizava a violência doméstica. Assim, as vítimas retornavam para seus lares sem nenhuma proteção após o pedido de socorro nas instâncias jurídicas, sendo convocadas posteriormente para uma audiência em que se tentava a reconciliação do casal mesmo depois da prática de violência (FERNANDES, 2015).

Avaliando as principais características das audiências preliminares de conciliação adotadas em instâncias jurisdicionais especiais, como os juizados criminais, Cappelletti (1988) pontua que essas consistem em um procedimento informal, discreto e de caráter predominantemente público, adaptado para o atendimento de partes desacompanhadas de advogados. Nesse sentido, Lei 9099/95 prevê a obrigatoriedade dessa assistência apenas para o autor do fato, conforme o disposto nos artigos 68, 71 e 72 do diploma legislativo.

Nesse sentido, não se verifica a mesma atenção para com a assistência das vítimas, haja vista o entendimento de que essas postulam direitos disponíveis, raciocínio razoavelmente compatível com a natureza dos crimes de menor potencial ofensivo, mas extremamente incoerente com a violência de gênero em geral.

Desse modo, as experiências vivenciadas a partir da aplicação da estrutura legislativa e processual dos juizados especiais criminais para tratamento de crimes envolvendo violência doméstica revelaram-se extremamente desastrosas, haja vista a desatenção para com as peculiaridades afetas à violência de gênero e ausência de estratégias institucionais para um enfrentamento condizente com a complexidade do problema.

Aprofundando essa discussão, Fernandes (2015) pontua que a aplicação da Lei 9099/95 aos crimes de violência doméstica e familiar contra a mulher implicou na completa anulação de todos os avanços institucionais experimentados pelo Brasil ao longo das últimas décadas quanto à compreensão e enfrentamento da violência de gênero enquanto problema grave e digno de preocupação das autoridades competentes.

Antes da promulgação da Lei Maria da Penha, a aplicação da Lei 9099/95 aos casos de violência doméstica e familiar contra a mulher, e consequente fixação da competência de conhecimento e julgamento desses crimes nos juizados especiais criminais, contribuíram significativamente para alimentar o sentimento de impunidade ante as condutas delituosas dos agressores e o completo menosprezo das diversas modalidades de violações suportadas pelas vítimas, haja vista a tipificação dessas enquanto crimes de menor potencial ofensivo, conforme pontua Izumino (2003).

A aplicação do instrumental legislativo e processual dos juizados a esses crimes implicou ainda na invisibilidade das consequências destrutivas oriundas da violência sobre a qualidade de vida, autoestima e saúde das vítimas, preocupação que foi registrada apenas a partir da promulgação da Lei Maria da Penha, que colocou no mesmo plano de gravidade a violência física, psicológica, moral e patrimonial contra a mulher.

A mobilização feminista em torno dos direitos das mulheres e os demais movimentos sociais 
interessados nesta pauta contribuíram significativamente para a rediscussão do espaço conferido àquelas na sociedade e afirmação da paridade de direitos com o homem quanto ao exercício de funções idênticas.

Nessa perspectiva, as conquistas socais repercutiram significativamente no plano jurídico, haja vista a promulgação de dispositivos que estabeleceram a igualdade entre homens e mulheres em direitos e obrigações (art. 5º I da Constituição de 1988) e a revogação de comandos discriminatórios como o Código de Processo Penal instituído pelo Decreto 3.689/41. Esse dispositivo condicionava o direito de queixa da mulher agredida ao consentimento do marido, permitindo que fosse exercido sem anuência expressa desse apenas se a mulher fosse separada ou caso a queixa não fosse contra o companheiro (FERNANDES, 2015).

Considerando que já existe disciplina legal para a violência de gênero no Brasil, a Lei Maria da Penha, deve esse diploma normativo ser o instrumento legislativo mais adequado para tratamento da pornografia de vingança, o que implica em transpor a competência de conhecimento e julgamento do delito em pauta para as varas especializadas da mulher e da violência doméstica.

O referido diploma normativo foi promulgado no âmbito do enfrentamento à violência doméstica e familiar praticada contra a mulher, considerando a dimensão de valor atribuído à família, estrutura base do Estado, principalmente visando proteção integral à dignidade da mulher, cujos direitos fundamentais são assegurados para que essa desfrute de paridade de direitos com o homem, gozando destes independentemente de classe, raça, etnia, orientação sexual, renda, cultura, nível educacional, idade e religião.

O rol de atitudes caracterizadas como violência contra a mulher foi consideravelmente alargado pela Lei Maria da Penha, que além de considerar como agressão doméstica as violações que incidem sobre o corpo da mulher, tipifica também as violências psicológicas, morais e patrimoniais, enumeradas no artigo 70 da mencionada lei.

Nessa perspectiva, Fernandes (2015) observa que a violência física consiste na ofensa da integridade ou saúde corporal da mulher, implicando em danos à saúde ou integridade física, deixando ou não marcas aparentes. De acordo com a Autora, a gravidade das lesões indica vias de fato, lesão corporal- entendida como dano à integridade física e mental-tortura, homicídio, entre outros.

Por sua vez, a violência psicológica demarca a vigência do processo de dominação da vítima pelo agressor mediante atitude de controle e rebaixamento da mesma. Observada de maneira sutil em seus estágios iniciais, instrumentaliza o controle emocional da vítima. Assim, a violência psicológica não consiste em um ato isolado, mas em um padrão de relacionamento, de crimes em concurso, cíclica e infinitamente repetidos das mais diversas formas.

As consequências desse tipo de violência são extremamente destrutivas e variadas, compreendendo entre 
as suas principais manifestações: dano emocional, diminuição da autoestima, prejuízo do pleno desenvolvimento, degradação da vítima, controle de suas ações, comportamentos, crenças e decisões (FERNANDES, 2015).

Nesse sentido, violência psicológica constitui um tipo de violência doméstica de gênero que merece atenção peculiar, tendo em vista que, quer ocorra em meio a outros tipos de violência, quer se apresente de modo isolado, implica em sofrimento intenso para as vítimas, que normalmente a descrevem como mais intenso que a agressão física.

Dessa forma, considerando o seu poder de dano e ou consequências para a vítima, deve ser compreendida como ameaça à saúde, haja vista a urgência de interpretações transdisciplinares para descrever esse elemento. (SAUAIA; ALVES, 2015). Consoante o entendimento de da Sauaia e Alves (2015) existem fundamentos científicos sólidos para a tipificação da violência psicológica, manifestação da violência de gênero, como crime de lesão corporal à saúde com base no caput e $\$ 9^{\circ}$, do art. 129, do Código Penal brasileiro, combinado com o art. 7º, II, da Lei 11.340/2006. Os estudiosos destacam que apesar dos estudos disponíveis tanto no âmbito de atuação do Ministério Público quanto do Poder Judiciário ainda é rara a condenação do agressor unicamente devido à prática de violência psicológica doméstica e de gênero.

Finalmente, a Lei Maria da Penha também dedicou especial tratamento à violência moral, conduta delituosa que implica no sofrimento das vítimas através da prática de calúnias, injúrias ou difamações, incidindo de forma muito agressiva sobre as mulheres, considerando a rigidez com que a sociedade ainda valora a moralidade feminina.

Nessa perspectiva, destaca-se a perfeita correspondência entre essa modalidade de violência e a pornografia de vingança, entendida como exposição não autorizada da intimidade da vítima, cuja conduta moral tende a ser inevitavelmente reprovada e a violência moral. Essa modalidade de violência prevista na Lei Maria da Penha, que a caracterizada como violência de gênero, revela-se muito mais compatível com os delitos em discussão do que a mera ofensa moral indiferenciada tipificada no Código Penal.

Nessa perspectiva, a compreensão da pornografia da vingança enquanto violência psicológica implicará em consequências jurídicas importantes, como, por exemplo, o atendimento humanizado das vítimas, acompanhamento dessas por equipe interdisciplinar, indisponibilidade da ação penal e possibilidade de aplicação de medidas protetivas pelo juízo competente, além de acompanhamento de vítima e agressor por diversas instituições, considerando a gravidade da violência.

Além da maior aderência ao escopo de assegurar a integridade mental da mulher vítima de pornografia da vingança, observa-se também a adoção de um modelo processual que melhor disciplina o prosseguimento da ação penal, em caso de aplicação da Lei Maria da Penha, tendo em vista a indisponibilidade da ação, qualificação 
que implica no compartilhamento de interesses do Estado e da vítima.

\section{CONCLUSÃO}

A divulgação não autorizada da sexualidade feminina como forma de represália ante o fim de relacionamentos tem se apresentado como crime recorrente no cenário mundial, exigindo dos juristas brasileiros soluções jurídicas que ultrapassem a mera subsunção simplista dos casos concretos à disciplina legal.

Dada a clara caracterização do fenômeno como violência de gênero, impondo-lhe complexidade específica e o alto poder destrutivo da conduta delituosa sobre as vítimas bem como a infinidade de dispositivos tecnológicos hábeis para a prática desse tipo de violência contra a mulher, observa-se que o enfrentamento do problema torna-se desafio inadiável para as instituições do sistema de justiça.

Para tanto, a Lei Maria da Penha se apresenta como o instrumento normativo mais apropriado para o tratamento da pornografia de vingança, haja vista a adoção de abordagens transdisciplinares para compreensão da violência de gênero e previsão legal de estrutura institucional e garantias processuais condizentes com a complexidade das demandas envolvendo violência de gênero,

No entanto, o que se observa é a ausência de compreensão dos operadores do direito quanto à natureza de violência de gênero da pornografia de vingança, que se apresenta, em geral, sob a forma de lesão à saúde psicológica advinda da prática de violência psicológica e/ou moral, condutas claramente previstas na Lei Maria da Penha.

A dificuldade em interpretar adequadamente a pornografia de vingança resulta em grande medida da formação legalista e simplista ofertada aos juristas nas instituições de ensino superior, instrumental teórico que, ainda fundado predominantemente no positivismo, determinismo e racionalismo científico, já não se mostra adequado ao enfrentamento dos problemas sociais modernos, caracterizados por especificidades sócioculturais complexas.

A pornografia de vingança, por exemplo, é o exemplo emblemático de que já não se pode mais falar atualmente de separação entre as violências de gênero praticadas em circunstâncias presenciais e virtuais, considerando que o único critério para distinção dessas duas instâncias relacionais é a intensidade e o poder destrutivo da última, elemento acentuado nas violações perpetradas com auxílio da internet. Desse modo, tornase necessária a superação da dicotomia on line versus off line para efetivo enfrentamento das modalidades de violência de gênero comtemporâneas.

Considerando o entendimento jurisprudencial majoritário no sentido de enquadramento da pornografia 
de vingança enquanto crime contra a honra, advindo da incompreensão da natureza real do fenômeno enquanto violência de gênero, configura-se a negligência para com a proteção da integridade física ou psicológica da vítima, que se encontra dessa forma vulnerável ante às lesões causadas à sua saúde.

A falta de percepção da pornografia de vingança como crime intrafamiliar de gênero induz a fixação da competência de conhecimento e julgamento desses delitos nos juizados especiais criminais haja vista a aderência aos crimes de menor potencial ofensivo como injúria, difamação e delitos cibernéticos.

Desse modo, se deixa de aplicar a Lei Maria da Penha, legislação mais adequada à complexidade do crime, que fixa a competência para tratamento desses nas varas da mulher e da violência doméstica, unidades institucionais com estrutura multidisciplinar melhor preparada para recebimento dessas demandas.

Essa aptidão das varas da mulher para tratamento da pornografia de vingança se revela a partir da percepção das variadas modalidades de violência doméstica contra a mulher estabelecidas na Lei Maria da Penha, atendimento humanizado, acompanhamento de vítimas e agressores por equipes muldisciplinares, bem como a existência de garantias processuais que protegem a vítima, considerando que essa se encontra em posição de vulnerabilidade específica advinda das graves violações sofridas.

Por sua vez, a estrutura processual dos juizados especiais criminais se revela claramente incompatível com o tratamento da pornografia de vingança, considerando a percepção equivocada no sentido de que essa é crime de menor potencial ofensivo, o que naturaliza, trivializa e estimula o comportamento impune dos agressores.

Isso acontece porque os juizados especiais criminais foram criados em uma conjuntura política de ampliação do acesso à justiça dos cidadãos às demandas consideradas de menor complexidade jurídica, destoando completamente do contexto de promulgação da Lei Maria da Penha, criada com o escopo de coibir os índices atíssimos de incidência da violência contra a mulher no Brasil, pandemia que demanda seu enfrentamento eficiente pelo Estado.

Antes mesmo da promulgação da Lei Maria da Penha, as experiências concretas demonstraram a evidente falta de aptidão dos juizados especiais criminais para tratamento dos crimes envolvendo violência de gênero. Observou-se que esses representaram a completa anulação de todas as conquistas das mulheres quanto ao enfrentamento da violência doméstica.

Todos esses retrocessos institucionais causados pelo tratamento da violência de gênero a partir dos juizados criminais ressurgem atualmente, quando se observa a percepção e definição da competência afeta à pornografia de vingança, haja vista a inobservância das diferenciações de gênero, elementos determinantes para a compreensão do delito, que deslocam a competência de seu processamento para a Lei Maria da Penha. 


\title{
THE INCOMPATIBILITY BETWEEN THE PROCESSUAL MODEL OF SPECIAL CRIMINAL FORUMS AND THE COMPLEXITY OF REVENGE PORN
}

\begin{abstract}
This is a study about the incompatibility between the institutional structure of special criminal forums in Brazil, described in the 9099/95 Law and the efective repression of the revenge porn, gender violence that requires the application of the Maria da Penha Law, therefore the designation of the competence for reception and judgment of these crimes on specialized foruns of women and domestic violence against women. Emphasis the unprepared of lawyers in the establishment of jurisdiction, which naturalizes the serious consequences of revenge porno on the lives of victims, comparing this crime with less serious crimes, those disconnected from their nature of intrafamily gender violence. Discuss about the problems in this definition of competence in the effective confrontation of gender violence, pointing to the adoption of transdisciplinary approaches as the best way to understand and to fight the complexity of revenge porn, rethinking the jurisdictional competence for confront this crime. In order to achieve this objectives, were adopted this search proceedings: field research, documentary research, bibliographic research, normative research and content analysis to process the results obtained.
\end{abstract}

Keywords: Revenge Porn, Gender Violence, Maria da Penha Law, 9099/95 Law, Special Criminal Forums.

\section{REFERENCIAS}

BAUMAN, Z. Globalização: as Consequências Humanas. Rio de Janeiro: Jorge Zahar Editor, 1999.

BOURDIEU, P. A Dominação Masculina. Rio de Janeiro: Ed. Bertrand Brasil, 2003.

CAPPELLETTI, M; GARTH, B. Acesso à Justiça. Porto Alegre: Ed. Sérgio Antonio Fabris, 1988.

CASTELLS, M. A Galáxia da Internet: reflexões sobre a internet. Rio de Janeiro: Zahar,1999.

CAVALCANTE, V. A.P; LELIS, A.G. S. Violência de gênero contemporâneo: Uma Nova Modalidade através da Pornografia da Vingança. Interfaces Científicas - Direito. Aracaju, v.4, n.3, p. 59 - 68, jun. 2016. Disponível em:< https://periodicos.set.edu.br/index.php/direito/article/view/31 18/1849>. Acesso em 20 mai 2017. 
FARIA, F. C. M; ARAÚJO, J. S; JORGE, M. F. Caiu na Rede é Porn: Pornografia de Vingança, Violência de Gênero e Exposição da "Intimidade". Contemporanea/ Comunicação e Cultura. V. 13, nº 03, p. 659-667, set-dez 2015 , p. 659-677.

Disponívelem:<https://portalseer.ufba.br/index.php/contemporaneaposcom/article/view/13999/10888>. Acesso em 02 jul 2017.

FERNANDES, V. D. S. Lei Maria da Penha: O Processo Penal no Caminho da Efetividade: Abordagem Jurídica e Multidisciplinar. São Paulo: Atlas, 2015.

FRANKS, M. A. Drafting An Effective "Revenge Porn” Law: A Guide for Legislators. 2015. Disponível em: <http://www.endrevengeporn.org/guide-to-legislation/> Acesso em 01 Mai. 2015.p. 3.

INSTITUTO AVON. Violência contra a mulher: o jovem está ligado? Disponível em: $<$ http://agenciapatriciagalvao.org.br/wp-content/uploads/2014/12/pesquisaAVON-violenciajovens_versao02-12-2014.pdf>. Acesso em: 24 ago 2016.

IZUMINO, W. P. Justiça para todos: os Juizados Especiais Criminais e a violência de gênero. Tese de Doutorado em Sociologia. Universidade de São Paulo (USP), 2003.

LÉVY, P. Cibercultura. Rio de Janeiro: Editora 34, 2008.

LINS, B. A. Vazou na internet: gênero, violência e internet nos debates sobre "pornografia de vingança. Disponível em: < www.30rba.abant.org.br/arquivo/downloadpublic?q>. Acesso em 1 mai 2017.

MENEZES, M. R. C. de; CAVALCANTI, V. R. S. Direitos e tempos virtuais: violências contra a mulher na cibercultura. Revistas de Artes de Humanidades, nº14 maio-out, 2016.

RINGROSE, J; RENOLD, E. Slut-shaming, girl power and 'sexualisation': thinking through thepolitics of the international SlutWalks with teen girls, Gender and Education, 24:3, 333-343, 2012.

SANTOS, B.S. Os Tribunais nas Sociedades Contemporâneas. Porto: Edições Afrontamentos, 1996. 
SIBILIA, P. O Show do Eu: A Intimidade como Espetáculo. Rio de janeiro: Nova Fronteira, 2008.

SILVA e SILVA, A; MANSO, A.G. Ciberfeminismo o Feminismo en la Red: Haciendo Arqueología en Internet. Antropología Experimental, no 17/2017.

SILVA e SILVA, A da; MANSO, A. G. ¿Normas y géneros?: performatividad en Judith Butler y la teoría ciberfeminista. Revista Latina de Sociología. vol. 6(2) (2016) pp. 63-102.

SILVA, A. M. F; SILVA, C. K. O Problema da Tipificação dos Crimes Informáticos: Aspectos Controversos a Respeito da Aplicação do Artigo 154-a da Lei no 12.737/2012 “Lei Carolina Dieckmann” In: BORGES, P. C. C; CARVAlHO, E. M; MELlO, M. M. P. (Coord). Direito Penal, Processo Penal e Constituição II. Florianópolis: Conselho Nacional de Pesquisa e Pós-Graduação em Direito (CONPEDI), 2014. Disponível em: <http:/ / www.publicadireito.com.br/artigos/?cod=2a5b63fbaadcaa8c> . Acesso em 14 ago 2016.

SILVA, A. S; ALVES, J. M. A Tipificação da Lesão à Saúde Psicológica: Revisitando o art. 129 do Código Penal à luz da Lei Maria da Penha in: Conselho Nacional de Pesquisa e Pós-Graduação em Direito. Direitos e garantias fundamentais I. Florianópolis: CONPEDI, 2016.

TSOULIS-REAY, A. A brief history of revenge porn: A few years ago, having your compromising photos fall into the wrong hands was a nightmare scenario. Now it's a genre. 2013. Disponível em: <http://nymag.com/news/features/sex/revengeporn-2013-7/>-Acesso em: 10 nov. 2015.

PROGRAMA DE APOIO A REDES DE MULHERES DA ASSOCIAÇÃO PARA O PROGRESSO DAS COMUNICAÇÕES. Vozes dos Espaços Digitais: Violência contra a Mulher relacionada à Tecnologia. Disponível em:< http://www.genderit.org/sites/default/upload/38_violenciacontramulher_politics 12.pdf>. Acesso em 12 mai 2017.

Trabalho enviado em 19 de março de 2018

Aceito em 05 de julho de 2018 